\title{
Victory' Verdict: The Violent Occupation of Territory in Hellenistic Interstate Relations
}

\author{
Angelos Chaniotis
}

\section{The question: Does violence establish property rights?}

Historians of law and anthropologists have identified several features of international law. It requires a ratified -preferably a written-set of statutes, a generally recognized authority that can force conflicting parties to accept these rules and can impose sanctions on the party that violates them, and the consistent application of these statutes. ${ }^{1}$ A ratified, generally accepted and written set of statutes regulating interstate conduct does not seem to have existed in ancient Greece, and the only authority that was believed to have ultimately controlled and sanctioned the deeds of the mortals was that of the gods. Yet, despite the lack of a written set of statutes, the Hellenistic Greeks treated the violent occupation of territory in such a consistent way that we have to assume that they had clearly defined concepts and principles, although they were equally weak in implementing decisions based on these principles as the modern instruments of international law are today.

Indeed, it would be surprising if the Greeks had not developed concepts concerning problems with which they were continually confronted. Phenomena such as the violent occupation of territory, raids, the seizure of persons, or the treatment of prisoners already occupy a prominent position in our earliest literary and documentary sources. ${ }^{2}$ The subject of violence in "international

1. E. M. Harris, "Antigone the Lawyer, or the Ambiguities of Nomos", in E.M. Harris and L. Rubenstein (eds.), Law and Courts in Ancient Greece, London, 2004, p. 19-56.

2. For the occupation of territory see more recently J.-M. Bertrand, "Territoire donné, territoire attribué: note sur la pratique de l'attribution dans le monde impérial de Rome", Cahiers du centre Gustave-Glotz, 2, 1991, p. 131-4; L. Boffo, "Lo statuto di terre, insediamenti e persone nell'Anatolia ellenistica. Documenti recenti eproblemi antichi", Dike, 4, 2001,p. 233-55; A. Chaniotis, "Justifying 
law" gained great prominence in the Hellenistic period. More wars were fought in this period than in any other earlier period, more territories changed hands violently than ever before, and naturally more sources survive: proxeny decrees that guarantee asphaleia and asylia, decrees that recognize the inviolability of poleis and sanctuaries, treaties regulating international arbitration, protocols of arbitrations, documents concerning the abuse of power by garrison soldiers etc. This documentation shows that the Hellenistic Greeks were continually confronted with the problem of violence in their interstate contacts. And yet we receive little information about a systematic treatment of this subject in public discourse.

One of the few exceptions is the protocolle of an arbitration of Magnesia on the Maeander between the Cretan cities of Hierapytna and Itanos (112 BC), ${ }^{3}$ in which we find a plaidoyer for the peaceful resolution of conflicts, a condemnation of conflicts and a praise of peace and concord; just as circumstances often bring even the closest relatives into conflict, it is the duty of their friends to try their best to reconcile them (lines 14-17); this is the reason why the Magnesians had willingly accepted the task of resolving the dispute. When the judges' final effort to reconcile the Hierapytnians and the Itanians failed, they were left with no other choice than to give a verdict which opens with a theoretical statement about the arguments that can be used to support a claim of ownership (kyrieia) over land:

Men have proprietary rights over land either because they have received the land themselves from their ancestors, or because they have bought it for money, or because they have won it by the spear, or because they have received it from someone of the mightier.

Territorial Claims in Classical and Hellenistic Greece”, in E.M. Harris and L. Rubenstein (eds.), Law and Courts in Ancient Greece, London, 2004, p. 185-212. For raids and seizures see B. Bravo, "Sulân. Représailles et justice privée contre des étrangers dans les cités grecques", $A S N P, 10,1980$, p. 675-987. For captives see A. Bielman, Retour à la liberté. Libération et sauvetage des prisonniers en Grece ancienne, Paris, 1994. For the treatment of prisoners of war see P. Ducrey, Le traitement des prisonniers de guerre dans la Grèce antique des origines à la conquête romaine, Paris, 1999.

3. I. Cret. III iv 9. Recent edition of the entire document and bibliography: S.L. Ager, Interstate Arbitration in the Greek World, 337-90 BC, Berkeley-Los Angeles-London, 1996, no. 158 II (cited as Ager, Arbitration). For a more detailed discussion of the legal aspects of this text see J.-M. Bertrand, art. cit., p. 126-45; F. Guizzi, “Conquista, occupazione del suolo e titoli che danno diritto alla proprietà: l'esemio di uno controversia interstatale cretese”, Athenaeum, 85, 1997,

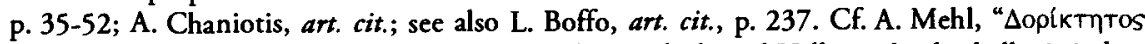
$\chi$ úpa. Kritische Bemerkungen zum Speererwerb in Politik und Völkerrecht der hellenistischen Epoche", Ancient Society, 11/12, p. $206 f$. 
Inheritance, purchase, and donation are three undisputed modes of acquisition of property; ${ }^{4}$ at first sight, the judges regarded conquest, the violent occupation of what belonged to another community, as one of the legitimate means of acquisition of property, without any further specification. Most of the Greeks would not have been shocked by such a statement. The national legends of most Greek communities contained a successful act of violence that had established its ownership of its territory. Aristotle himself recognized war as one of the skills by which men acquire the ownership of goods (Pol. II 1256b23). It is not hard to find further evidence in the Classical period for the belief that victory in war legitimizes the possession of the property of the defeated party. Thucydides, e.g., claims that according to the customary law of the Greeks the successful use of violence establishes rights:

The Greeks have a law (nomos) that whoever has under his power (kratos) a piece of land, whether big or small, also owns (gignesthai) the sanctuaries, managing them in the same manner as before to the best of his ability. For the Boeotians, as well as most other men, have used violence to expel another group of people and now hold (nemontai) their land, having as their own (oikeia kekteisthai) those sanctuaries, which belonged to others (allotriois) when they first came upon them. ${ }^{5}$

The object taken violently by means of conquest becomes the property (oikeia kekteisthai) of the victorious party. ${ }^{6}$ We find the same idea in a letter contained in the corpus of Demosthenes' orations and attributed to Philip; it concerns Philip's claims on Amphipolis. The letter is probably not authentic, but one observes that Philip's arguments find close parallels in arguments known from later documentary sources. The Macedonian king explains that three principles justify his claim: inheritance, conquest, and concession on the basis of a treaty:

For if (Amphipolis) belongs to those who have taken control of it originally, then who can say that I do not possess it justly, since Alexander, my ancestor, occupied that place first? [...] But even if someone should dispute this and demands that it should belong to those who became its sovereign owners later, then I have this right as well. For I defeated after siege those who had expelled you and had been settled there by the Lacedaemonians, and captured the fort. Indeed, all of us inhabit our cities either because our ancestors have handed them over to us or because

4. For examples see F. Guizzi, art. cit;; L. Boffo, art. cit.; Chaniotis, art. cit.

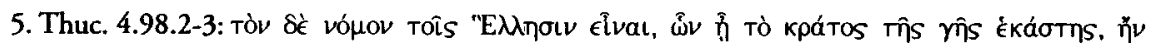

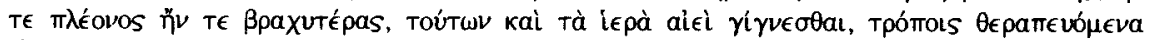

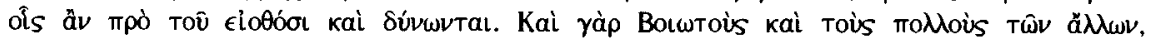

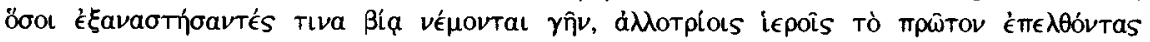

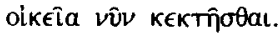

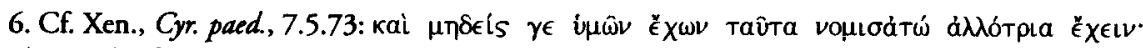

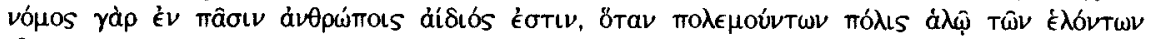

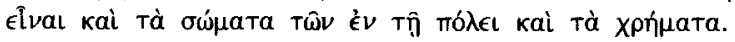


we have become their sovereign owners in war... Which other possession can be more secure than the possession (of Amphipolis), which was originally occupied by our ancestors, and became again ours in war, and thirdly was conceded (to us) by you, who have the habit of laying claim even to the cities which have nothing to do with you?

We encounter in this text a combination of three different justifications: original occupation, conquest in war, recognition in a treaty. ${ }^{8}$ The combination of different justifications, each one of them refering to a different time, presupposes that the claim on property is subject to changes: an inherited or purchased object may change its owner through an act of violence; and this act of violence may be later ratified by means of a contract.

\section{The terminus a quo}

A crucial consequence stems from the fact that property is subject to changes by different means (purchase, conquest, donation, inheritence): in order to answer the question who is the legitimate owner of a territory one needs first to determine a terminus a quo.

The Hellenistic Greeks and the Romans did draw this conclusion and in many documents concerning arbitration we find explicit references to the historical moment which should be the basis of a verdict. ${ }^{9}$ In the disputes for

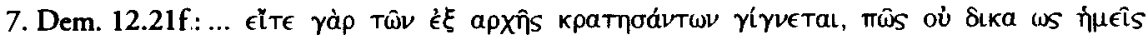

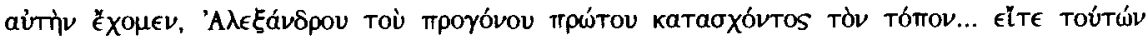

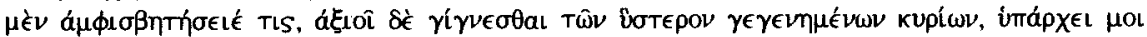

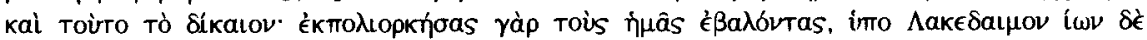

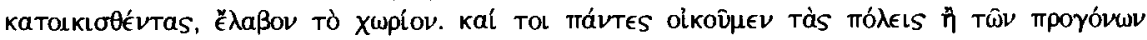

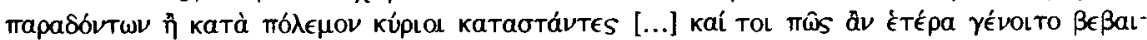

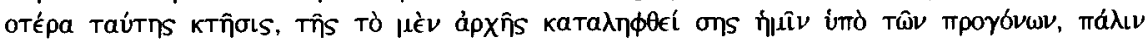

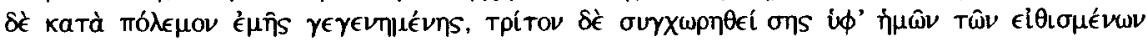

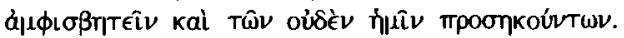

8. For a similar combination of victory in war and recognition in a treaty see the letter of Eumenes

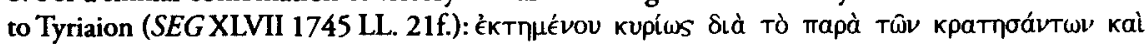

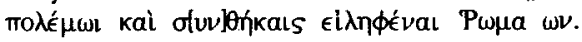

9. A.J. Marshall, "The Survival and Development of International Jurisdiction in the Greek World under Roman Rule", ANRW, II.13, p. 648f; R. Scuderi, "Decreti del senato per controversie di confine in età repubblicana", Athenaeum, 69, 1991, p. 371-415. (with further bibliography); K. Harter-Uibopuu, Das zwischenstaatliche Schiedsverfabren im achäischen Koinon. Zur friedlichen Streitbeilegung nach den epigraphischen Quelken, Köln-Weimar-Vienna, 1998, p. 170. In the conflict between Magnesia and Maeander (c. 175-160) the terminus a quo was the moment when Magnesia and Priene became allies of the Romans: Ager, Arbitration, no. 120 II, lines 20-22. In the conflict between Melitaia and Narthakion (c. 140) it was the moment they were accepted as amici of the Romans: Ager, Arbitration, no. 156. In the conflict of Hierapytna and Itanos (140 and $112 \mathrm{BC}$ ) it was the coming of Roman envoys in $140 \mathrm{BC}$; Ager, Arbitration, no. $158 \mathrm{I}$, lines $21 \mathrm{f}$, , 56-9, 64-7 and II, lines 51-4. In the conflict of Sparta and Messene (138 BC) it was the coming of L. Mummius to Greece in 146 BC: Ager, Arbitration, no. 159, lines 52-5. 
which we have sufficient documentation we may observe that the rights established through violence are not subject to controversy; the real controversy is the determination of the terminus a quo.

This is the way we should approach the negotiations between Antiochos III and the Romans in $196 \mathrm{BC}$ The Romans asked Antiochos to retire from the cities previously subject to Philip. According to Polybios (18.49-51) the senate's envoy, L. Cornelius Lentulus, argued as follows: "It was a ridiculous thing that Antiochos should come in when all was over and take the prizes they had gained in their war with Philip." When the Romans raised claim on these areas because of their victory over Philip V, Antiochos did not question this principle, he only moved the terminus a quo further to the past: another, earlier act of violence had established his claim, i.e. the victory of Seleukos I in 281 BC Again Polybios summarizes his argument (18.51):

He said that he had crossed to Europe with his army for the purpose of recovering the Chersonese and the cities of Thrace, for he had a better title to the sovereignty of these places than anyone else. They originally formed part of Lysimachos' kingdom, but when Seleukos went to war with Lysimachos and conquered him in the war, the whole of Lysimachos' kingdom came to Seleukos by right of conquest. But during the years that followed, when his ancestors had their attention deflected elsewhere, first of all Ptolemy and the Philip had robbed ( $\sigma \phi \in T \in \rho \sigma a \sigma$ $\theta a \mathrm{l})$ them of those places and appropriated them. At present he was not possessing himself of them by taking advantage of Philip's difficulties, but he was repossessing of them by his right as well as by his might.

In Antiochos' view the victory at Kouropedion had established his righteous claim on areas earlier occupied by the defeated king. ${ }^{10}$

We may be certain that this was not only Antiochos' view. Part of the land acquired by Seleukos after his victory was sold by his son and successor Antiochos I to Pitane. Exactly this land later became the object of dispute between Mytilene and Pitane. ${ }^{11}$ The many documents quoted in the verdict of the Pergamene arbitrators (lines 133-144) leave no doubt that the question they had asked was whether this transaction was lawful or not (cf. lines 149f: a $\sigma \phi a l \lambda$--

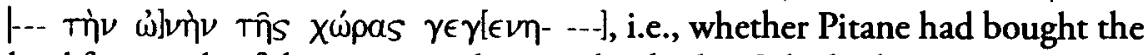
land from its lawful owner, in other words whether Seleukos' victory at Kouro-

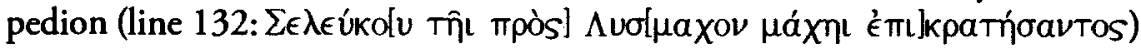
had made him and his successors lawful owners of the land and therefore gave them the right to sell it. The Pergamene judges recognized this right, which had already been confirmed earlier by Philetairos and Eumenes I. We see that

10. The negotiations between the Romans and Antiochos has often been the subject of detailed analysis. See esp. A. Mehl, art. cit. (note 3), p. 173-7 (with earlier bibliography).

11. Ager, Arbitration, no. 146, lines 130-50; cf. L. Boffo, art. cit. (note 2), p. 239f. This has been overlooked by A. Mehl, art. cit. 
in a comparable dispute both the Pergamene rulers and the Pergamene judges applied exactly the principle that Antiochos was defending against the Roman claims: The victory at Kouropedion had made his house the legitimate owner of the territory previously owned by Lysimachos. When Antiochos I sold part of this land to Pitane he did so as the legitimate owner and the subsequent claims of Pitane were valid, as deriving from this legitimate transaction.

But if violence constitutes a legitimate form of acquisition of property, then why did Antiochos deny this right to the Romans? In order to answer this question we have to turn our attention again to other pieces of evidence that show that the specific circumstances of the conquest made a world of a difference.

\section{The exact circumstances of conquest}

How the circumstances of the conquest affected the legitimacy of ownership through victory in war can been seen, again, in the case of Amphipolis. Aeschines claimed that a treaty which Amyntas had drawn up upon oath awarded the city to the Athenians; however, the resistance of the Amphipolitans prevented the Athenians from taking control of the city. In 360 Perdiccas, Philip's brother, conquered Amphipolis, but after his death (359) Philip relinquished control over the city to avoid challenging Athenian claims. The city managed to retain its autonomy until Philip reconquered it in 357 . Aeschines explains the arguments of the Athenians that were more than just a technicality:

If you argue that you reasonably possess Amphipolis by having taken it in war, if you had won the city with spear fighting against us, then you would be the sove-

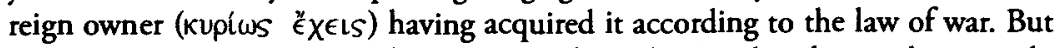
if you have taken the city of the Athenians from the Amphipolitans, then you do not possess their property, but the territory of the Athenians. ${ }^{12}$

Not unlike Antiochos, Aeschines does not question the right of conquest. On the contrary, he admits that the Philip's right of conquest was consistent with "the law of war". What undermined Philip's claim on the city was the fact that Philip had taken Amphipolis not from its lawful owners (the Athenians), but from the Amphipolitans. Antiochos argued along the same lines: his ancestors had never lost their territories in an open war with the Ptolemies or with Philip V. They were "robbed" in a moment in which they had their attention deflected elsewhere. ${ }^{13}$

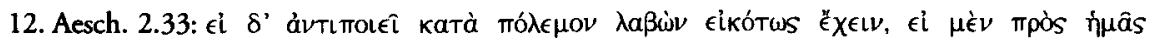

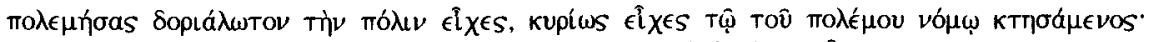

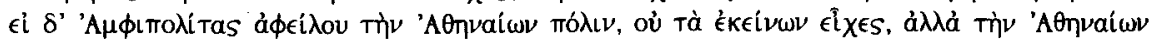
Xúpav.

13. This was rightly pointed out by E. Bickermann, "Bellum Antiochicum", Hermes, 67, 1932, p. 50-3. 
That this was not a technicality or a rhetorical device can be inferred from a similar situation with regard to Philip's claims on Halonnesos, which had previously belonged to the Athenians. When Philip took the island defeating the pirates who had occupied it, this did not affect the Athenian claim on the island. For this reason Demosthenes insisted that Philip should not "give", but "return" the island to the Athenians. ${ }^{14}$ Giving is the right of the lawful owner, and Philip was not the rightful owner.

The Hellenistic documentary sources contain more examples of this kind of argument. The conflict between Nagidos and Arsinoe over a territory provides a characteristic example of the consistent application of this principle. The Nagideis give their version of the controversy in a decree (lines 19-27):

When Aetos, son of Apollonios, a citizen of Aspendos and of our own city, became a general in Kilikia, he occupied a suitable site and founded a city by the name of Arsinoe, named after the king's mother. He settled new settlers here and he divided the land, which was ours (Tìv X

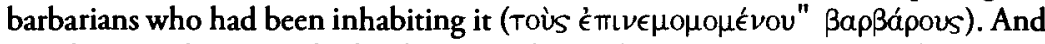
now his son Thraseas, who has been sent by the king as a general in Kilikia, shows great zeal in his efforts to make the city more glorious, and he has asked us to give

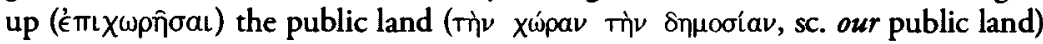
to the inhabitants, so that they may possess it ( $\chi \chi[\epsilon\llcorner v])$ for all time, they and their descendants. ${ }^{15}$

As we may see, Nagidos regarded a territory as its lawful property although it had been occupied by barbarians. When a Ptolemaic general expelled these barbarians, occupied the land, and founded a new city there, the Nagideis still regarded this land as their own public land. From their point of view, they had never lost ownership, despite these changes, presumably because they had not lost this land after a defeat in (a just) war.

The dispute between Samos and Priene over a strip of land called Batinetis is very similar. ${ }^{16}$ When king Lysimachos was asked to arbitrate in 283/2, the disputed territory was in the possession of the Samians, but the Prienians claimed that it had originally belonged to them. They had temporarily lost it in the 7th century BC, during the Cimmerian invasion under Lygdamis, but after a period of three years the land was "returned" to them. It is crucial to observe

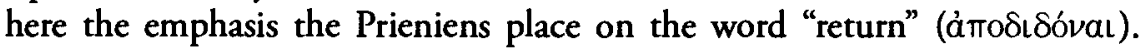
A conflict between Mytilene and Pitane may present a similar case. As we have seen, Pitane had bought a disputed territory from Antiochos I, who had inherited it from Seleukos I; the latter had occupied it after his victory over Lysima-

14. Dem. 7.5; 12.14; cf. Aesch. 3.83 .

15. SEG XXXIX 1426; Ager, Arbitration, no. 42. For a new edition of the text see G. Petzl, "Das Inschriftendossier zur Neugründung von Arsinoe in Kilikien: Textkorrekturen", Epigraphica Anatolica, 139, 2002, p. 83-8 (with the earlier bibliography).

16. Ager, Arbitration, no. $74 \mathrm{I}$. 
chos. If the Mytileneans could still claim this land as their own, it was possibly because Seleukos had not conquered it from them, but from Lysimachos.

Not every military victory established legal claims. The circumstances of the conquest were in important factor that was seriously taken into consideration.

\section{The justification of violence}

Finally, there is yet another parameter that plays an important part in the arguments presented by the conflicting parties: was the war that led to the conquest unprovoked or unjust? Conquest in general did not create the right of ownership, but only violence undertaken as a result of provocation or as vengeance for injustice. ${ }^{17}$ Although the Magnesian judges, Thucydides or Xenophon (see above $\$ 1$ ) did not make such a distinction, the legitimacy of the act of violence appears to have played a key role. The fact that the Greeks, both in legend and in historical documents, tried to present just causes is clearly related to this principle, on which Babrius (Fab. 99) has given his ironical comment:

Once a wolf saw a lamb that had gone astray from the flock, but instead of rushing upon him to seize him by force, he tried to find a plausible complaint $\left(\epsilon^{*} \gamma \kappa \lambda \eta \mu a\right.$ $\epsilon \dot{U} \operatorname{ló}^{\circ}(\omega \pi \mathrm{r})$ by which to justify his hostility. "Last year, small though you were, you slandered me." "How could I last year? It's not yet a year since I was born." "Well, then, aren't you cropping this field, which is mine?" "No, for I've not yet eaten any grass nor have I begun to graze." "And haven't you drunk from the fountain which is mine to drink from?" "No, even yet my mother's breast provides my nourishment". Thereupon the wolf seized the lamb and while eating him remarked: "You're not going to rob the wolf of his dinner even though you do find it easy to refute all my charges" (máonv aitínv).

One finds evidence for this differentiation in Demosthenes' Against Ctesiphon, where the orator denounces Philip's aggression: the Macedonian king had won by the spear some of the cities of the Athenians, "without having first suffered injustice at the hands of the Athenian people." ${ }^{n}$ The orator is not criticizing conquest in general, but unjustified, unprovoked conquest (oủ $\delta \grave{v} v$ $\pi \rho \circ a \delta \operatorname{sik} \theta \in \in(s)$. The importance of this distinction can be seen in a document of an entirely different nature, a curse tablet deposited in a grave in Oropos. An anonymous man curses a series of persons, hoping that the gods of the underworld would respond to his request and punish his opponents precisely because he had been wronged without having wronged them first. ${ }^{19}$

17. Cf. E. Bickermann and J. Sykoutris, Speusipps Brief an König Philipp, Leipzig, 1928, p. $27 f$.

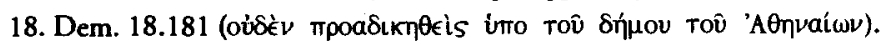

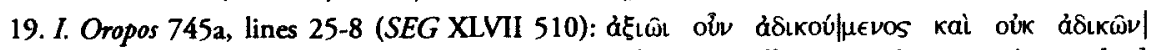

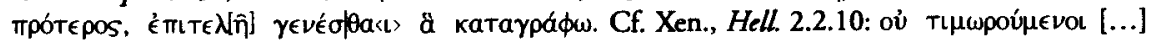
خं́íkouv. 
This idea persisted until the late Hellenistic period. When envoys of Hierapytna appeared before the Roman senate to defend their claims over a disputed territory, they made sure to mention the fact that they had not attacked or wronged their adversary, Itanos. ${ }^{20}$

\section{Legitimate violence: the importance of making distinctions}

Let me summarize the three points made so far: 1) Violent occupation of land or property was regarded as a legitimate form of acquisition of property, no less legitimate than inheritence, purchase or donation.

2) When the parties to a conflict based their claims on different arguments, neither the arbitrators nor the adversaries gave priority to a certain type of argument over another (e.g., inheritence over conquest), but determined a terminus a quo for the possession.

3) The exact conditions of the act of violence were important factors. Two questions played an important part: Did the conquest take place in a direct confrontation between the owner and the aggressor? Was the war justified?

These distinctions, which were consistently made from the mid-fourth century BC onwards, in no way limited the validity of violence as a basis for property claims in international law. The right of conquest was not questioned or criticized. What was questioned were the circumstances, not the principle.

The principle that the violent conquest of foreign land establishes a legitimate ownership is therefore neither a literary fiction, nor a Hellenistic innovation, nor an arbitrary claim made by the Magnesian judges. This idea was connected with the belief that success in a violent activity (war, piracy, or raid) cannot be achieved without the support of the gods and may be viewed as the punishment of the defeated party. The most instructive example of a defeat in war seen as punishment for unjust behavior is that of Athens' defeat in the Peloponnesian War. As Xenophon explains, the Athenians believed they suffered not for the punishment they inflicted on others, but for the injustices they committed through their own arrogance. ${ }^{21}$

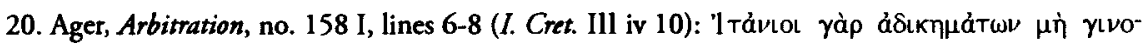

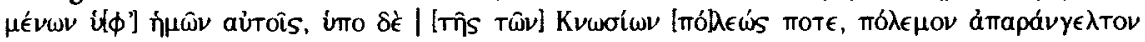

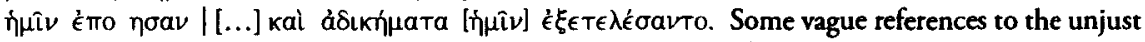
or unlawful occupation of a territory may in fact be connected with this line of argument. See, e.g., the conflict between Narthakion and Melitaia (Ager, Arbitration, no. 156 lines 23f.: Eautûv ásíkus | ['́moúnaavt]o).

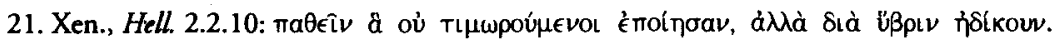


Divine support for acts of piracy is implicilty recognized in the custom of dedicating a tithe of the booty to the gods -a thanksgiving dedication corresponding to the idea of do ut des. ${ }^{22}$ An interesting appeal to this principle is found in the arguments made by the Samians in a conflict with Priene over the fort Karion and the region called Dryoussa. ${ }^{23}$ Their claim was confirmed through the 'verdict of their victory' in a battle against the Prienians

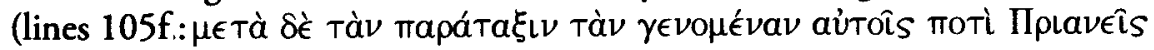

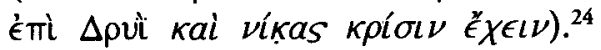

In the Hellenistic period in particular the idea that violence (in the form of victory in war) establishes rights was strengthened through its connection with the ideology of Hellenistic monarchy, ${ }^{25}$ A prayer in Pergamon for the success of King Attalos III expresses, e.g., the wish that the gods give him victory and success not only in his defensive wars (amynomenoi), but also in his offensive wars (archonti)". ${ }^{26}$

22. e.g., Meiggs-Lewis, GHI, 16; Herod. 3.47.

23. Ager, Arbitration, no. $74 \mathrm{I}$.

24. For the "verdict of.battle" cf. Polyb. 13.3.4: Tìv ék Xєı

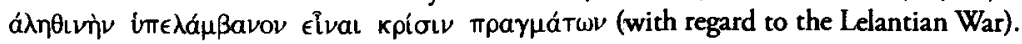

25. But see also the critical remarks by A. Mehl, art. cit. (note 3).

26. I. Pergamon 246, line 31. 